Role of agricultural engineering in FARM MACHINERY AND POWER environmental and sustainable development

for the valley and delta areas: 1092- 1110

\title{
EFFECT OF SUBSOIL TILLAGE ON POTATO RESPONSE TO BIOFERTLIZATION APPLICATION
}

\section{Dr Bahnas, O.T.* and Dr M.Y. Bondok}

\section{ABSTRACT}

This study was carried out at Kafr El-Gonena Village, El-Dakhlia Governorate, during 2008 winter season to identify effect of subsoil tillage on potato response to biofertilization application. The experiment was designed statistically as a split split plots with three replications. The main plots involved the subsoil tillage treatment at 0.30, 0.40 and $0.50 \mathrm{~m}$ depth, comparing with no-subsoil tillage, the sub plots involved the soil biofertilization treatment using Blue green Algae, comparing with the bereaved of biofertilization and the sub-sub plots included the tuber inoculation treatment using a combination of microorganisms, comparing with the bereaved of inoculation. The results indicated the following:

1. The subsoil tillage of $0.40 \mathrm{~m}$ depth under Blue green Algae application achieved the more desirable soil characteristics of 1.14 $\mathrm{g} / \mathrm{cm}^{3}$ bulk density, $6.04 \mathrm{pH}, 2.54 \mathrm{dS} / \mathrm{m}$ salinity, $14.14 \mathrm{~mm} / \mathrm{h}$ infiltration rate and 47, 17.90 and $497 \mathrm{ppm}$ available $N, P$ and $K$ concentration, respectively.

2. The subsoil tillage of $0.40 \mathrm{~m}$ depth under Blue green Algae application required the lower applied irrigation water amount of $5240 \mathrm{~m}^{3} / \mathrm{fed}$.

3. The subsoil tillage of $0.40 \mathrm{~m}$ depth under Blue green Algae application and tuber inoculation achieved higher potato tuber yield of $18.80 \mathrm{Mg} / \mathrm{fed}$ and higher water use efficiency of $3.58 \mathrm{~kg} / \mathrm{m} 3$.

Generally, it is recommended to apply the subsoil tillage under biofertilization application to achieve higher potato tuber yield.

\section{INTRODUCTION}

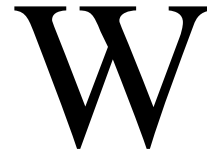
ith the steadily increasing the price of the chemical fertilizers and the pollution problems, the biofertilization application is becoming more and more important. Potato requires highly relative amount of chemical fertilizers. It requires about $120-150 \mathrm{~kg}$ $\mathrm{N} / \mathrm{fed}, 60-70 \mathrm{~kg} \mathrm{P} / \mathrm{fed}$ and $96 \mathrm{~kg} \mathrm{~K} / \mathrm{fed}$ (Ministry of Agriculture and

** Senior Researcher at the Ag. Eng. Res. Inst. (AEnRI), Giza.

* Researcher at the Ag. Eng. Res. Inst. (AEnRI), Giza. 
Land Reclamation, 2005). Biofertilizer is defined as live formulates of beneficial microorganisms, which when is applied to soil, roots or seeds, enhances the availability of different nutrients to the plant by its inherent metabolic activity (Higa, 1991). El-Karamany et al. (2000) stated that the biofertilizers significant effect may be due to effect of different strain groups and nutrients mobilizing microorganisms which help in availability of metals and their forms in the composted material and increased levels of extractable minerals. Beneficial microorganisms are these that can fix atmospheric nitrogen, decompose organic wastes, animal manures, detoxicty pesticides, suppress plant disease and soilborne disease (Parr and Hornick, 1994). Awad (1998) and Abdulla (1999)) reported that potato vegetative growth characteristics increased as a result of applying chicken manure combined with biofertilizer.

The compacted subsoil hard-pan would reduce potato yield and quality under different soil types (van Loon and Bouma, 1978, Wolfe et al., 1995 and Stahlman and Allen, 2001). It reduces nutrients diffusion and mechanical resistance to root growth and elongation, resulting in a limited area for both water and nutrient uptake (Wolkowski, 1990; Lowery and Schuler, 1994 and Laboski et al., 1998).

There is unintelligible image about the effect of subsoil tillage on potato yield and quality could be drawn. The use of subsoil tillage has been recommended by Stark and Love (2003)to alleviate the abominable effects of compacted layers on potato productivity. On the other hand, Holmstrom and Carter (2000) reported that subsoil tillage has not consistently improved yields of potato in compacted soils. He found that no evidence of improved potato yield or quality, and only marginal improvements in soil bulk density when subsoil tillage was used to loosen compacted subsoil hard-pan. Therefore, Ibrahim and Miller (1989); Miller and Martin (1990); Halderson et al. (1993) and Alva et al. (2002) stated that potato yield was only marginally affected by subsoil tillage because proper irrigation and water management alleviated any potential benefits.

This study aimed to identify the effect of subsoil tillage on potato response to biofertilizers application. 


\section{MATERIAL AND METHODS}

\section{Experimental Procedure:}

\section{Soil characteristics:}

A field experiment of 1 feddan $(70 \times 60$ m)was carried out during 2008 winter season at Kafr El-Gonena Village, El-Dakhlia Governorate. According to the standard procedures as cited by El-Serafy and ElGhamry (2006), the soil was analyzed mechanically as shown in table (1). Also, table (2) reveals some soil characteristics. Table (3) presents the soil hydrophysical properties which were determined using pressure extractor with regulated air pressure as pointed out by Garcia (1978).

Table (1): Soil mechanical analysis of the experimental site.

\begin{tabular}{|c|c|c|c|c|c|c|}
\hline \multirow{2}{*}{$\begin{array}{c}\text { Soil layer, } \\
\text { m }\end{array}$} & \multicolumn{3}{|c|}{ Sand, \% } & \multirow{2}{*}{ Silt, \% } & Clay, \% & Soil texture class \\
\cline { 2 - 6 } & Corse, \% & Fine, \% & Total, \% & & & \\
\hline $0-0.30$ & 9.00 & 8.30 & 17.30 & 48.53 & 34.17 & Silty clay loam \\
\hline $0.30-0.60$ & 9.10 & 7.30 & 16.40 & 46.00 & 37.60 & Silty clay loam \\
\hline
\end{tabular}

Table (2): Some soil characteristics of the experimental site.

\begin{tabular}{|c|c|c|c|c|c|c|c|}
\hline $\begin{array}{c}\text { Soil } \\
\text { layer, } \mathrm{m}\end{array}$ & $\begin{array}{c}\text { Moisture } \\
\text { content } \\
\text { (d.b.), } \%\end{array}$ & $\begin{array}{c}\text { Bulk } \\
\text { density, } \\
\mathrm{g} / \mathrm{cm}^{3}\end{array}$ & $\begin{array}{c}\mathrm{Ec}, \\
\mathrm{dS} / \mathrm{m}\end{array}$ & $\begin{array}{c}\mathrm{pH}, \\
1: 2.5\end{array}$ & $\begin{array}{c}\text { Available } \\
\mathrm{N}, \mathrm{ppm}\end{array}$ & $\begin{array}{c}\text { Available } \\
\mathrm{P}, \mathrm{ppm}\end{array}$ & $\begin{array}{c}\text { Available } \\
\mathrm{K}, \mathrm{ppm}\end{array}$ \\
\hline $0-0.30$ & 18.12 & 1.39 & 5.28 & 8.50 & 34.55 & 11.24 & 471.09 \\
\hline $0.3-0.6$ & 20.01 & 1.48 & 5.82 & 8.75 & 29.85 & 6.85 & 459.85 \\
\hline
\end{tabular}

Table (3): Some soil hydrophysical properties of the experimental site.

\begin{tabular}{|c|c|c|c|c|}
\hline $\begin{array}{c}\text { Soil layer, } \\
\mathrm{m}\end{array}$ & $\begin{array}{c}\text { Field capacity, } \\
\mathrm{Wt} / \mathrm{wt} \%\end{array}$ & $\begin{array}{c}\text { Wilting point, } \\
\mathrm{Wt} / \mathrm{wt} \%\end{array}$ & $\begin{array}{c}\text { Available water, } \\
\mathrm{mm}\end{array}$ & $\begin{array}{c}\text { Infiltration rate, } \\
\mathrm{mm} / \mathrm{h}\end{array}$ \\
\hline $0-0.30$ & 12.50 & 6.58 & 5.92 & 24 \\
\hline $0.30-0.60$ & 11.85 & 7.04 & 4.81 & 26 \\
\hline
\end{tabular}

\section{Agricultural practices:}

\section{a. Subsoil tillage:}

The subsoil tillage was carried out using a mounted single shank subsoiler. It was made from a toolbar with a three point hitch, it was linked with a straight shank made of rigid steel with dimensions of $0.80 \mathrm{x}$ $0.09 \times 0.03 \mathrm{~m}$. A mole-ball has cube shape of $0.10 \times 0.10 \times 0.10 \mathrm{~m}$ was 
linked with the shank. A four by four tractor with $120 \mathrm{~kW}$ power was used to mount and operate the subsoiler plough.

\section{b. Seed bed preparation:}

The seed bed was prepared using a chisel plough in two perpendicular directions at $0.20 \mathrm{~m}$ depth.

The secondary tillage was performed using a tandem disc harrow. The land leveling was carried out using a mounted hydraulic land leveler of $1.26 \mathrm{~m}^{3}$ capacity $(0.60 \times 3.00 \times 0.70 \mathrm{~m})$.

\section{c. Planting:}

An one row semi-automatic with horizontal divided tray planter was used to plant the cut potato seed tubers Sponta variety. It was operated at 1.30 $\mathrm{km} / \mathrm{h}$ forward speed using $2 \mathrm{WD}$ tractor of $48 \mathrm{~kW}$ power.

As the recommendations of the potato developing and training center (2001), the seed tubers were planted with a rate of $0.75 \mathrm{Mg} / \mathrm{fed}$ at $0.10 \mathrm{~m}$ planting depth, $0.75 \mathrm{~m}$ row spacing and $0.25 \mathrm{~m}$ hill spacing apart along the same furrow.

\section{d. Fertilization:}

1. The mineral $\mathrm{N}$ fertilizer in the form of ammonium sulfate $(21 \% \mathrm{~N})$ with a rate of $60 \mathrm{~kg} \mathrm{~N} / \mathrm{fed}$ was applied in two equal doses before planting and before the $1^{\text {st }}$ irrigation. Also, the $\mathrm{N}$ fertilization in the form of ammonium nitrate $(34 \% \mathrm{~N})$ with a rate of $60 \mathrm{~kg} \mathrm{~N} / \mathrm{fed}$ was applied in two equal doses before $2^{\text {nd }}$ and $3^{\text {rd }}$ irrigations.

2. The biofertilizer in the form of blue green Algae powder with the rate of $0.50 \mathrm{~kg} / \mathrm{fed}$ was applied, at the tenth day after sowing, it was mixed with a suitable quantity of softy soil, then, the mixture was broadcasted above the irrigation water surface.

3. Tuber inoculation was conducted using a combination of Azospirilium sp., Azotobacter sp., Bacillus mega-theruim var. phosphaticum, Pseudomonas sp. And Mycorriza sp. With a rate of $0.50 \mathrm{~kg} / \mathrm{ton}$ of potato tuber seeds.

\section{e. Irrigation:}

The border surface irrigation system was applied using an electric archimedean screw of $375 \mathrm{~m}^{3} / \mathrm{h}$ discharge.

As presented in table (4), the irrigation water was analyzed chemically according to El-Serafy and El-Ghamry (2006). 
Table (4): Irrigation water chemical analysis at the experimental site.

\begin{tabular}{|c|c|c|c|c|c|c|c|c|c|c|c|}
\hline \multirow{2}{*}{$\begin{array}{l}\text { Ph, } \\
1: 2.5 \\
\text { (susp.) }\end{array}$} & \multirow{2}{*}{$\begin{array}{l}E_{w}, \\
d S / m\end{array}$} & \multirow{2}{*}{$\begin{array}{c}\text { Total soluble } \\
\text { salts, ppm }\end{array}$} & \multicolumn{4}{|c|}{ Soluble anions, ppm } & \multicolumn{4}{|c|}{ Soluble cations, ppm } & \multirow[b]{2}{*}{ SAR } \\
\hline & & & $\mathrm{CO}_{3}$ & $\mathrm{HC}$ & $\mathrm{C}$ & Sc & C & & $\mathrm{N}$ & $\mathrm{K}$ & \\
\hline .37 & 4.43 & 2296.46 & 0.05 & 549.43 & 56.32 & 27.52 & 85.64 & 122.37 & 344.57 & 10.56 & 3.57 \\
\hline
\end{tabular}

The irrigation was scheduled during potato growth stages as follows:

1. 1 irrigation during sprout development stage at $50 \%$ of the available soil water.

2. 1 irrigation during vegetative groth stage at $50 \%$ of the available soil water.

3. 3 irrigations with interval of 14 days during tuber set initiation stage at $60 \%$ of the available soil water.

4. 3 irrigations with interval of 14 days during tuber bulking stage at $60 \%$ of the available soil water.

All other practices were done according to the recommendations of Potato and Vegetatively Propagated Vegetables Res. Dept., Horticulture Inst., Ag. Res. Center, Ministry of Agriculture and Land Reclamation.

\section{Treatments and statistical design:}

During the experiment, the following treatments were tested:

1. Subsoil tillage: It included the subsoil tillage depth levels of 0.30 , 0.40 and $0.50 \mathrm{~m}$, comparing with no-subsoil tillage (control). In each plot, two trenches were holed longitudinally at $6.00 \mathrm{~m}$ spacing apart. Also, two trenches at $0.50 \mathrm{~m}$ depth and $20.00 \mathrm{~m}$ spacing apart were digged horizontally to separate between each replication and the other.

2. Soil biofertilization: It included the soil biofertlization application using Blue green Algae, comparing with the bereaved of biofertilization (control).

3. Tuber inoculation: It included the tuber inoculation, comparing with the bereaved of inoculation.

The experiment was designed statistically as a split split plots with three replications. The main plots involved the subsoil tillage treatment levels, the sub plots involved the biofertilization treatment 
levels and the sub-sub plots included the tuber inoculation treatment levels.

\section{Measurements:}

\section{Soil characteristics:}

At harvest, the soil moisture content and the soil bulk density were determined according to ASAE (1992), the soil $\mathrm{pH}$ and the soil salinity were determined as cited by Black et al. (1965), the soil infiltration rate was determined according to Garcia (1978) and the available soil macronutrients concentration was determined according to Hesse (1971).

\section{Total amount of irrigation water:}

The total amount of irrigation water (TIW) was determined as follows:

$$
T I W=\frac{L R+C R}{\eta A} m^{3} / \mathrm{fed}
$$

Where:

$L R$ is leaching requirements, $\mathrm{m}^{3} / \mathrm{fed}$.

$C R$ is crop water requirements, $\mathrm{m}^{3} / \mathrm{fed}$.

$\eta \quad$ is irrigation system efficiency, $\%$.

$A$ is irrigated area, fed.

$L R$ is estimated as outlined by Doorenbos and Prutt (1977) as follows:

$$
L R=\frac{E C i}{E C_{d}}
$$

Where:

$E C_{i}$ is irrigation water electrical conductivity, $\mathrm{dS} / \mathrm{m}$.

$E C_{d}$ is drainge water electrical conductivity, $\mathrm{dS} / \mathrm{m}$.

The net crop water requirements and the irrigation interval (II) are calculated as cited by FAO (1979) and Israelson and Hansen (1962) as follows:

$$
\begin{aligned}
& W H C=(F C-P W P) p_{\mathrm{b}} \cdot \mathrm{d} .10 \mathrm{~mm} \\
& M a x \cdot C R=\frac{M A D \cdot W H C}{100} \mathrm{~mm}
\end{aligned}
$$




$$
\begin{gathered}
\text { Max.CR }=\frac{\text { Max.g.w.r }}{\eta} m m \\
\boldsymbol{I I}=\frac{\text { Max.CR }}{\text { Etcrop }} d a y \\
E t=E t_{0} \times k_{c} m m / d a y
\end{gathered}
$$

Where:

WHC. is soil water holding capacity, $\mathrm{mm}$.

$F C$ is soil field capacity, $\%$.

$P W P$ is soil permanent wilting point, \%.

$\rho_{b} \quad$ is soil bulk density, $\mathrm{g} / \mathrm{cm}^{3}$.

$\mathrm{D}$ is effective root zone depth, $\mathrm{m}$.

$M A D$ is management allowable deficit, $\mathrm{mm} / \mathrm{m}$.

Max. g.w.r is maximum gross water requirements, mm.

Et is net crop water requirements, $\mathrm{mm}$.

$E t_{0}$ is potential evapotranspiration, $\mathrm{mm} /$ day.

$K_{c}$ is crop factor.

$E t_{0}$ was calculated according to the data recorded by Kafr Ssad weather station, Domiat Governorate which is affiliated to the Central Laboratory for Agricultural Climate, Ministry of Agriculture and Land Reclamation. The irrigation water amount was measured using a rectangular shape crested weir. It was determined according to James (1988) as follows: $Q=k . c d . A \sqrt{H} \mathrm{~L} / \mathrm{s}$

Where:

$$
\begin{aligned}
& Q \text { is orifice discharge } \mathrm{L} / \mathrm{s} \\
& k \quad \text { is discharge coefficient. } \\
& c_{d} \text { is constant unit. } \\
& A \text { is orifice area, } \mathrm{m}^{2} . \\
& H \text { is effective water head over the orifice center, } \mathrm{m} .
\end{aligned}
$$

\section{Potato tuber yield:}

At harvest, for each experimental unit, an area of $1 \mathrm{~m}^{2}$ was selected randomly to determine the potato tuber yield.

\section{Water use efficiency (WUE):}

$$
W U E=\frac{\text { grain yield, } \mathrm{kg} / \mathrm{fed} .}{\text { appllied irrigation water amount, } \mathrm{m}^{3} / \mathrm{fed} .} \mathrm{kg} / \mathrm{m}^{3}
$$




\section{Statistical Analysis:}

SAS computer software package was used to employ the analysis of variance and the LSD tests for potato tuber yield data.

\section{Regression and Correlation Analysis:}

Microsoft Excel 2007 computer program was used to carry out the simple regression and correlation analysis to represent the relation between the subsoil tillage depth and the potato tuber yield.

\section{RESULTS AND DISCUSSIONS}

\section{Soil Characteristics:}

Through figures (1) to (8), it is clear that the subsoil tillage of $0.40 \mathrm{~m}$ depth under Blue green Algae application achieved the more desirable soil characteristics of $1.14 \mathrm{~g} / \mathrm{cm}^{3}$ bulk density, $6.04 \mathrm{pH}, 2.54 \mathrm{dS} / \mathrm{m}$ salinity, $14.14 \mathrm{~mm} / \mathrm{h}$ infiltration rate and 47, 17.90 and $497 \mathrm{ppm}$ available $\mathrm{N}, \mathrm{P}$ and $\mathrm{K}$ concentration, respectively.

It is obviously that the desirable effect of the subsoil tillage on the soil characteristics could be arranged in the following descending order: $0.40>0.50>0.30 \mathrm{~m}$ depth. This trend may be illustrated that as the subsoil tillage depth increased, the subsoiler mole-ball stacks the soil clods under its middle beating and shooting them upwards, which allows them to be charged with a higher kinetic energy, giving higher degree of soil rupture. Then, the irrigation water streams, detaches soil particles from the surface and pushes fine particles into surface pores, creating smaller pores which offer greater resistance to gravity, where they may impede gradually the infiltration process with the soil depth. Then, at the deeper soil layer, the exceed soil resistance against the subsoiler moleball the diminishes the soil rupture, resulting in lower soil pulverization, creating relative larger soil clods that increase slightly the soil infiltration process. Consequently, the soil characteristics relate strongly with the soil moisture content which is negatively proportional to the soil bulk density, $\mathrm{pH}$ and salinity, consequently, increasing the availability of macronutrients.

Also, data show the significant effect of the biofertilization on improving the soil characteristics. It is attributed to the biological process in which microorganisms decompose the soil organic materials, consuming oxgen and producing carbon dioxide, water and heat into the soil, maintaining the soil fertility. 


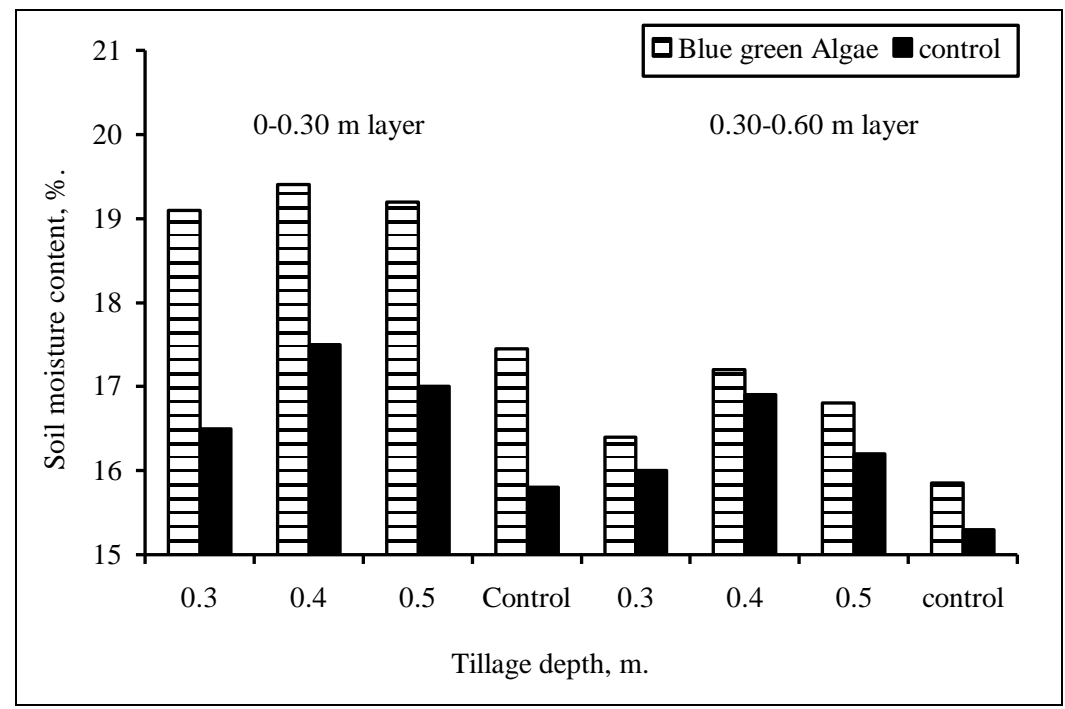

Fig. (1): Effect of subsoil tillage on soil moisture content.

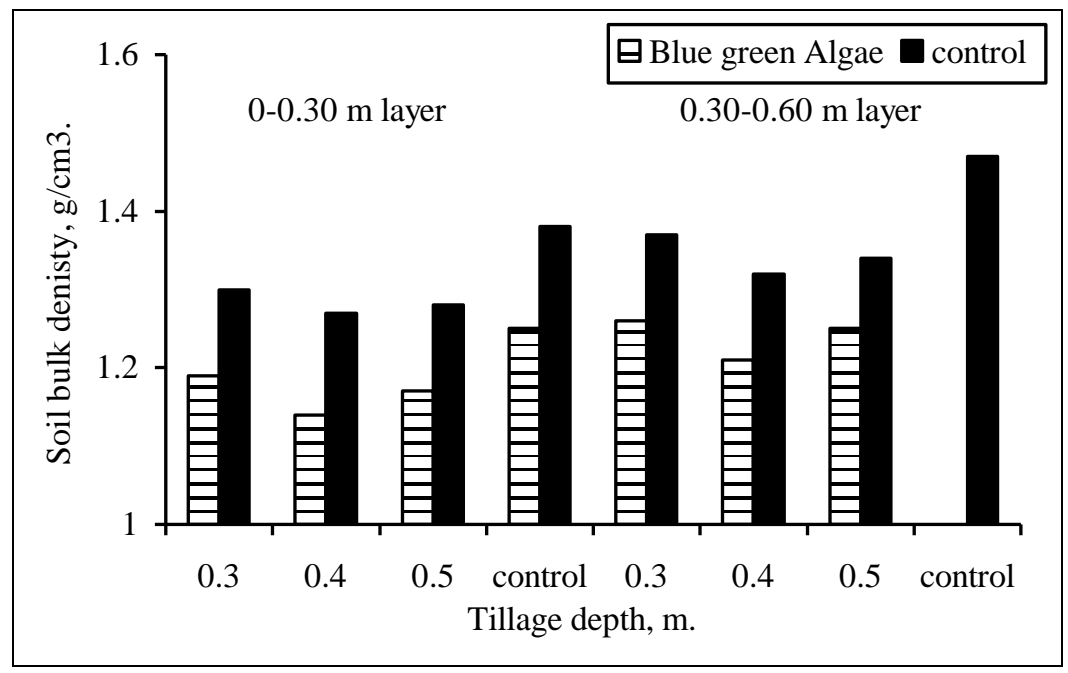

Fig. (2): Effect of subsoil tillage on soil bulk density. 


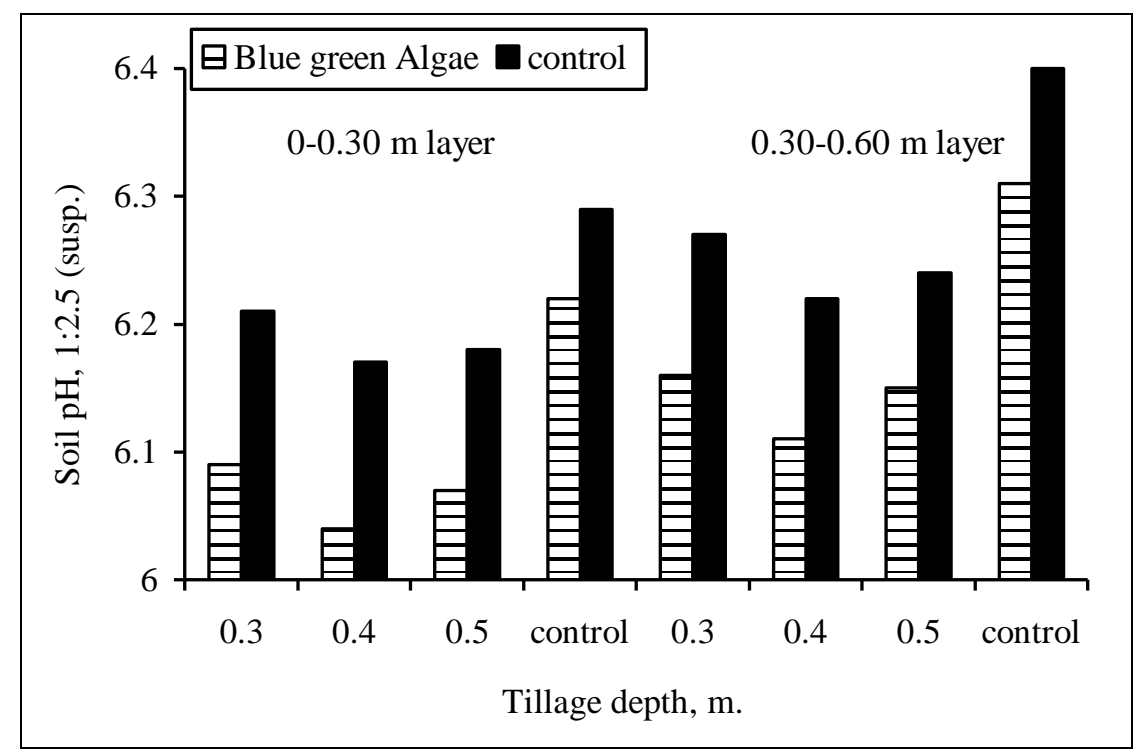

Fig. (3): Effect of subsoil tillage on soil $\mathrm{pH}$.

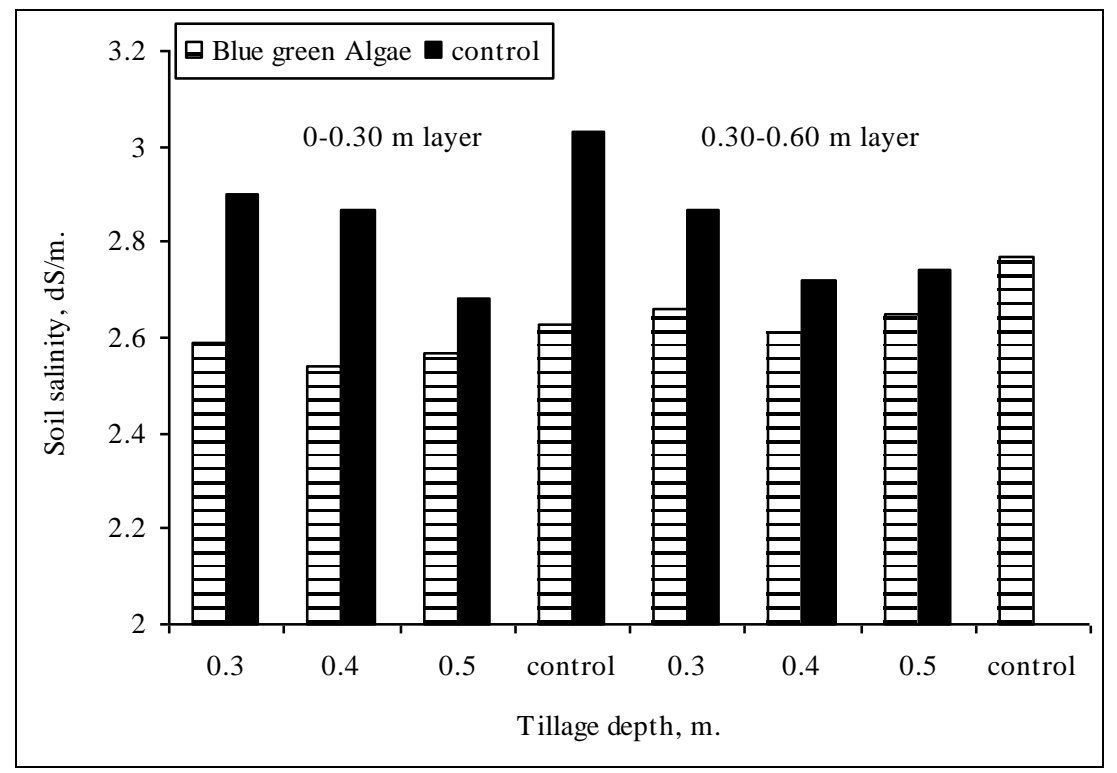

Fig. (4): Effect of subsoil tillage on soil salinity. 


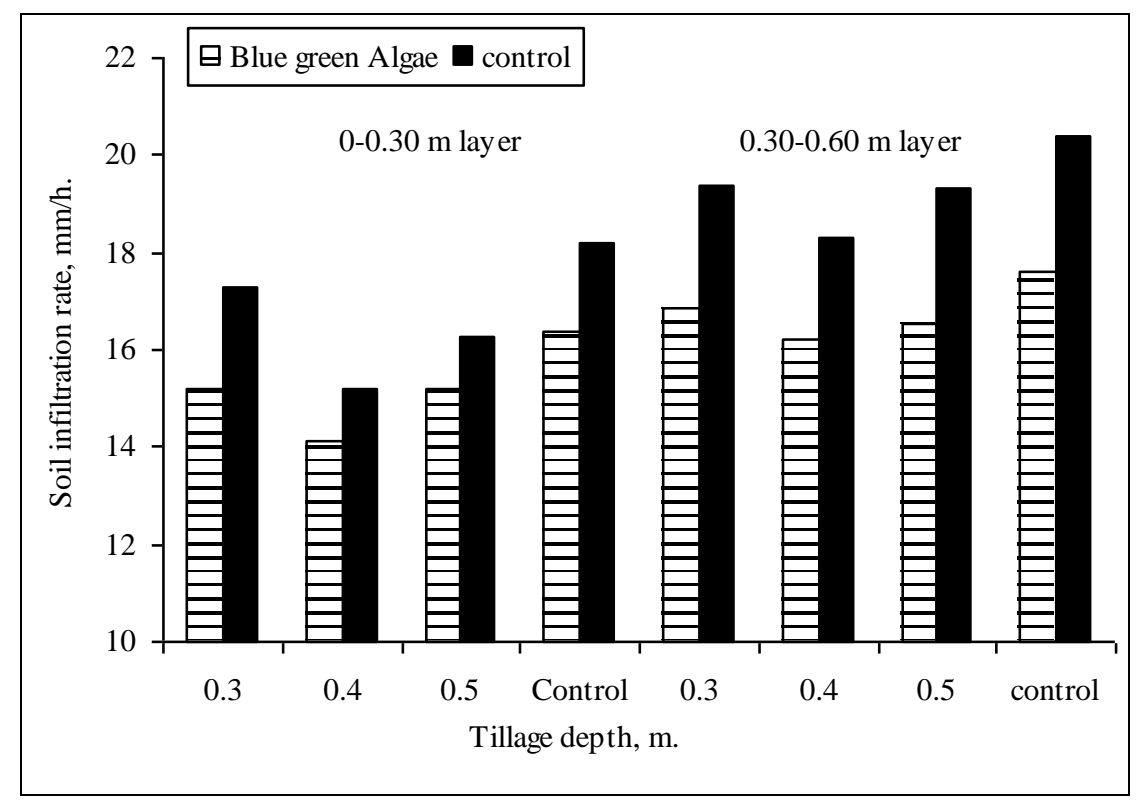

Fig. (5): Effect of subsoil tillage on soil infiltration rate.

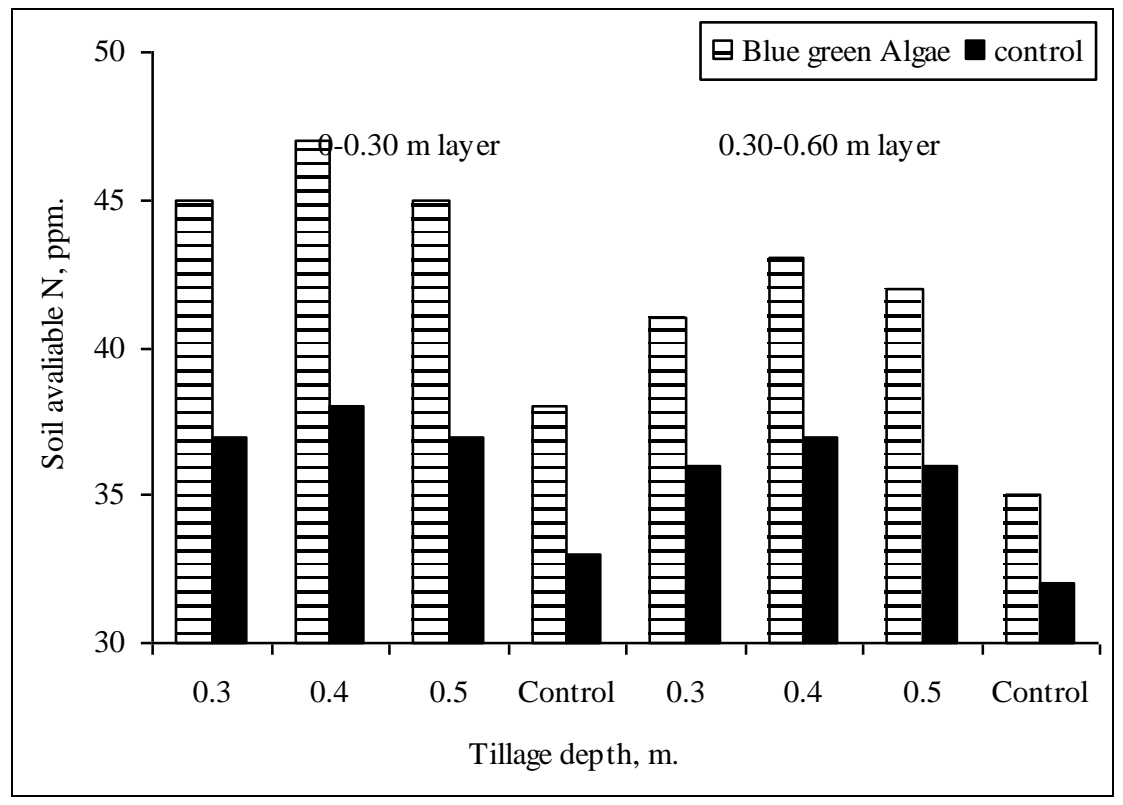

Fig. (6) Effect of subsoil tillage on soil available N. 


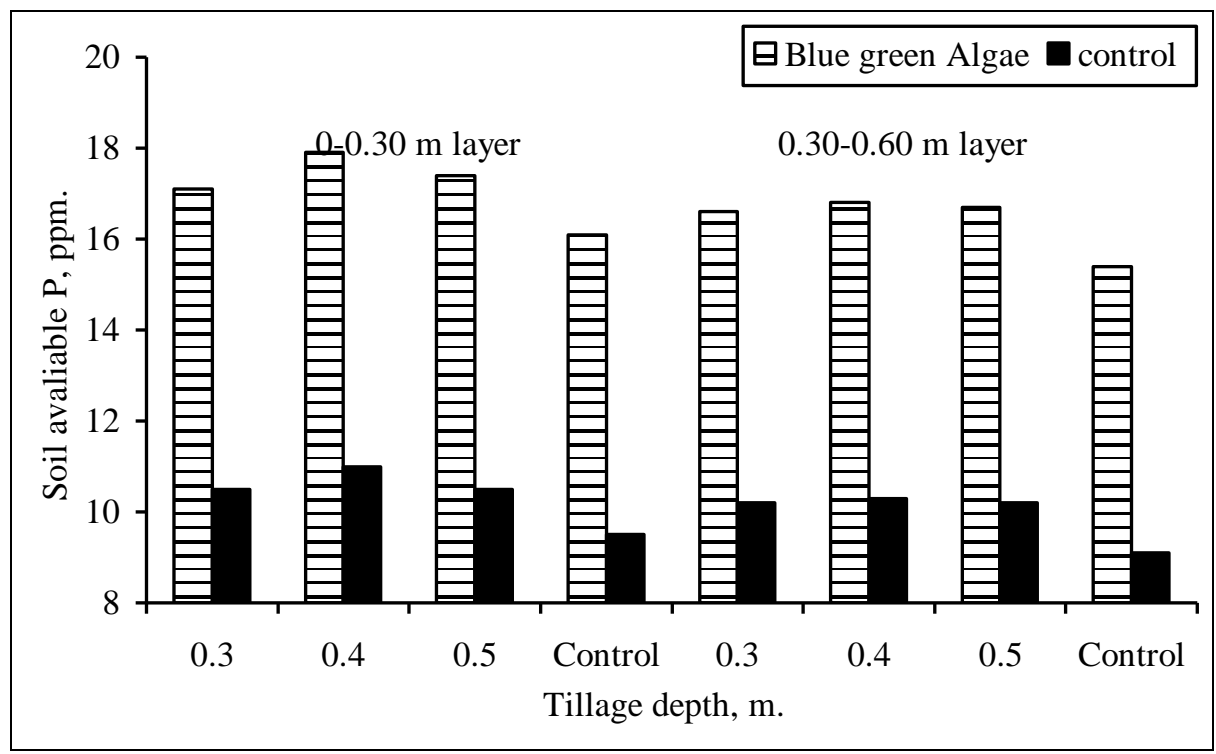

Fig. (7) Effect of subsoil tillage on soil available P.

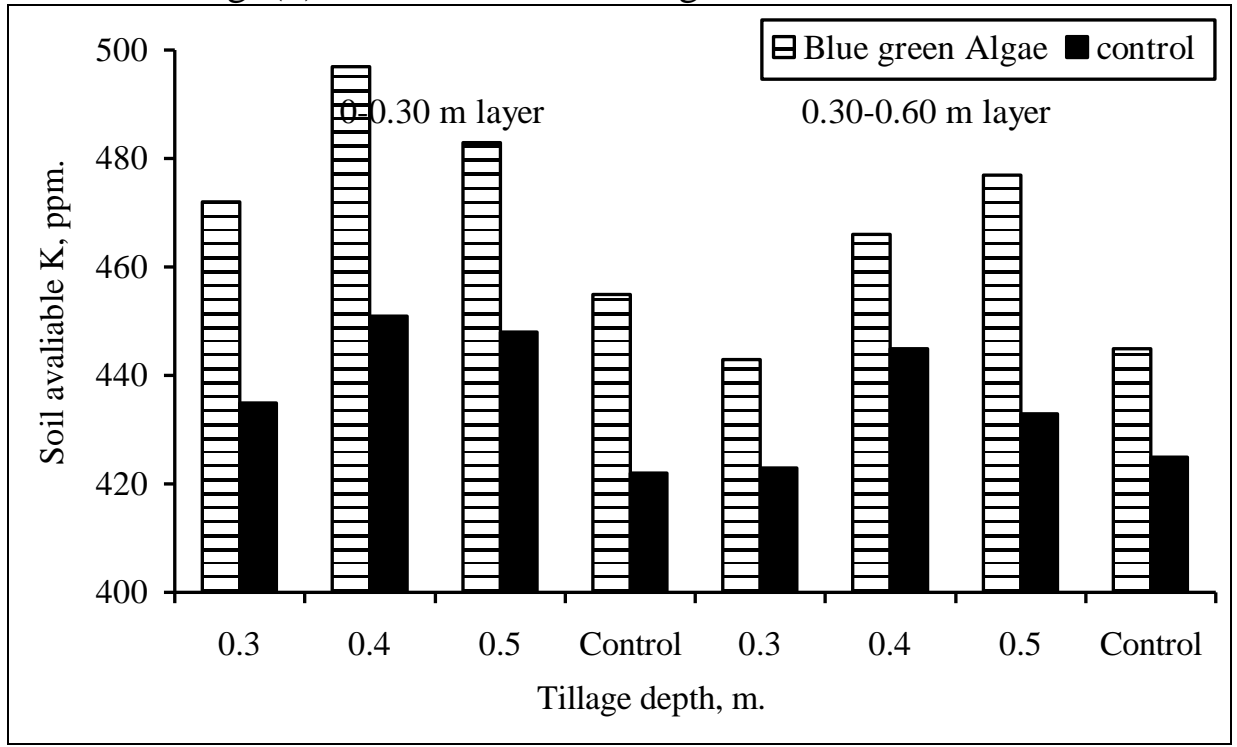

Fig. (8): Effect of subsoil TILLAGE on soil available K.

\section{Applied Irrigation Water Amount:}

Figure (9) demonstrates the effect of subsoil tillage under biofertilizer application on the applied irrigation water amount during potato growing stages. Data exhibits that the subsoil tillage at $0.40 \mathrm{~m}$ depth under Blue green Algae application required the lower irrigation water amounts of $1218,937,1400$ and $1685 \mathrm{~m}^{3} /$ fed during sprout development, vegetative 
growth, tuber set initiation and tuber bulking growing stages, respectively. In other meaning, it required the lower total irrigation water amount of $5240 \mathrm{~m}^{3} / \mathrm{fed}$ during the growing season.

Data shows that the subsoil tillage at $0.30,0.40$ and $0.50 \mathrm{~m}$ saved the total irrigation water amount by about $6.57,20.00$ and $14.00 \%$, respectively of the irrigation water amount that was required without using the subsoiler. It is due to the desirable soil characteristics after subsoiling which decreases the irrigation water losses by evaporation and run-off. On the other hand, the biofertilizer application at 0.30, 0.40 and $0.50 \mathrm{~m}$ subsoiling depth saved the total irrigation water amount by about $6.00,11.00$ and $11.00 \%$, respectively of the irrigation water amount that was required in case of the bereaved of biofertilizer application. This finding is illustrated that the biofertilization enhance to improve the soil structure, resulting in the increase of water retention.

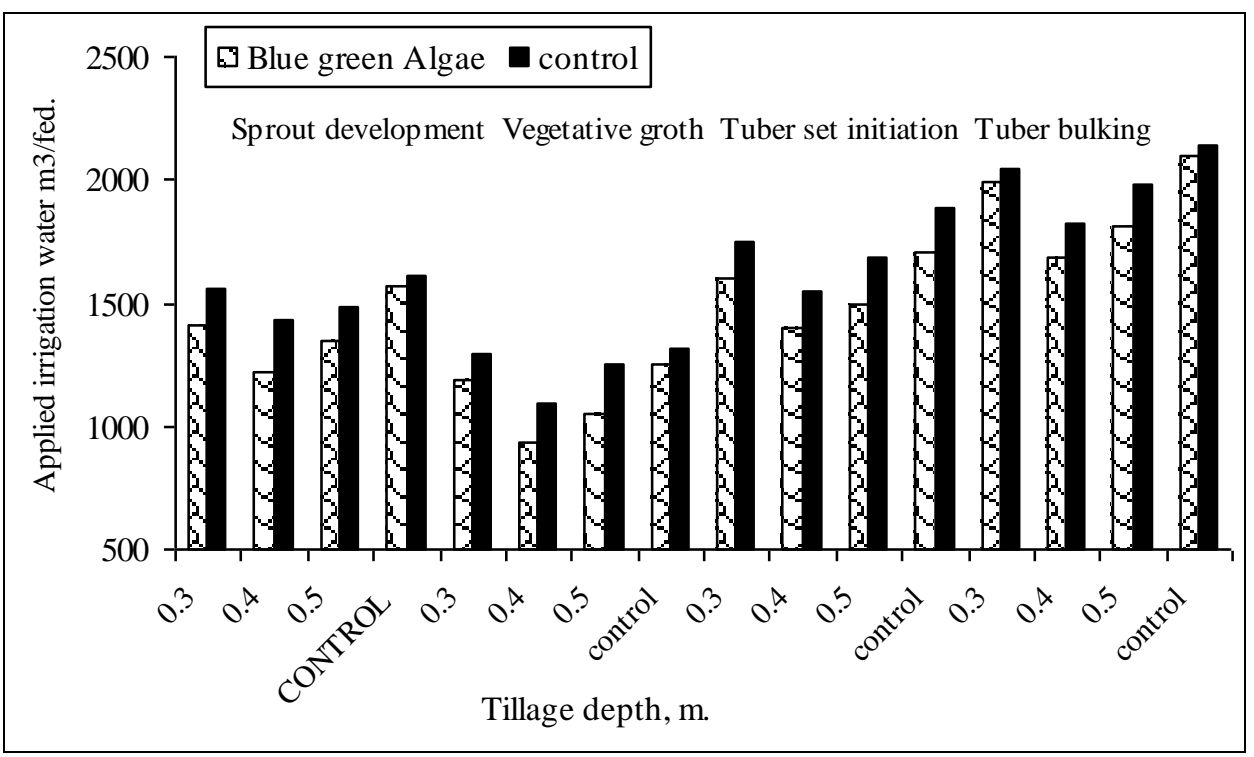

Fig. (9): Effect of subsoil tillage on applied irrigation water amount .

\section{Potato Tuber Crop Yield:}

Figure (10) clarifies that the higher potato tuber yield of $18.80 \mathrm{Mg} / \mathrm{fed}$ was obtained using the subsoil tillage of $0.40 \mathrm{~m}$ depth under Blue green Algae application and the tuber inoculation. Data exhibit that the subsoil tillage of $0.30,0.40$ and $0.50 \mathrm{~m}$ depth increased potato tuber yield by 
about $147.00,153.00$ and $148.00 \%$, respectively of the tuber yield value tha was obtained in case of no-subsoil tillage. This finding could be illustrated that the subsoil tillage leads to improve the soil drainage and aeration, which help plant roots to penetrate and well root distribute in the soil. Therefore, potato tuber yield was affected significantly using the biofertilizer. Blue green Algae application increased potato tuber yield by about $132.00,127.00$ and $135.00 \%$, at subsoil tillage depth of $0.30,0.40$ and $0.50 \mathrm{~m}$, respectively of the tuber yield value that was obtained in case of the bereaved of biofertilizer application. This finding is explained that biofertilizer improves the soil conditions, resulting in the increase of nutrients solubility and nutrient availability to the plants that enhance plant growth and development. In addition, the tuber inoculation influenced potato tuber yield positively. The tuber inoculation increased potato tuber yield by about $17.00,15.85$ and $16.00 \%$ at subsoil tillage depth of $0.30,0.40$ and $0.50 \mathrm{~m}$, respectively under biofertilizer application. This result could be explained that the inoculated biofertilizer with the combination of $\mathrm{N}$ mineral fertilization may increase the crude protein in the tuber tissues.

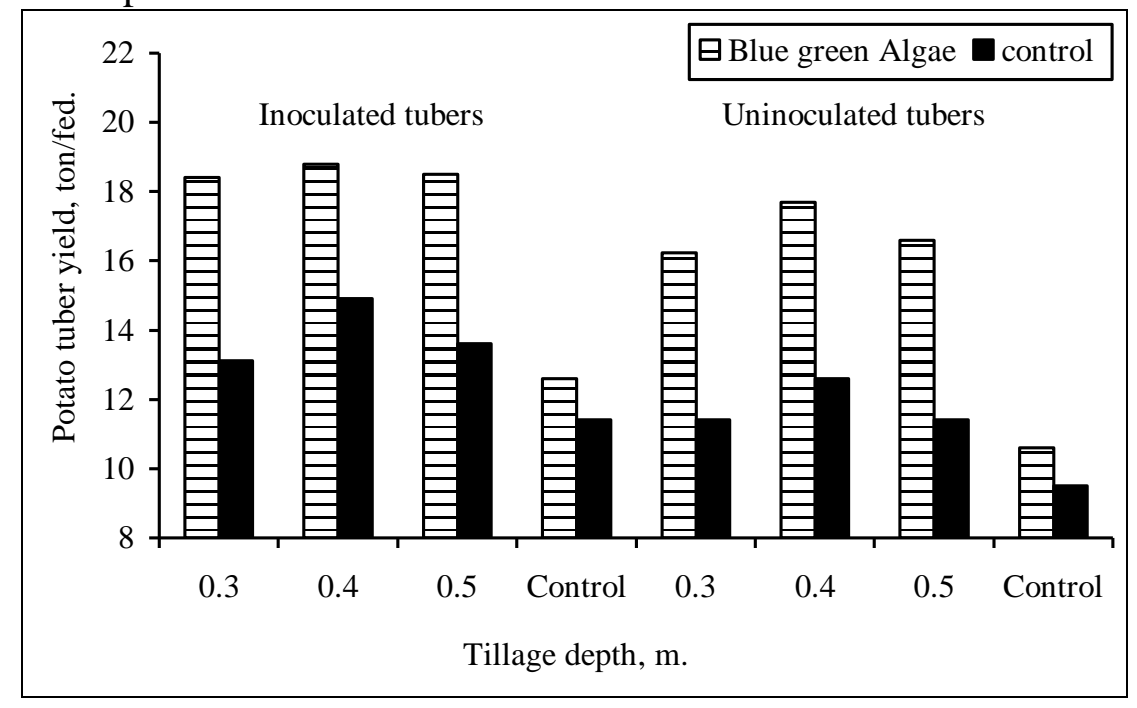

Fig. (10): Effect of subsoil tillage on potato tuber yield.

The analysis of variance test indicates that there is a highly significant difference in potato tuber yield due to the subsoil tillage and the biofertilization application. 
The L.S.D. test at 0.05 level shows that the subsoil tillage depth of 0.04 $m$ under Blue green Algae application and tuber inoculation achieved the highest potato tuber yield among the other treatments.

The regression and correlation analysis reveals that the potato tuber yield (y) correlates positively with the subsoil tillage depth (x) under Blue green Algae application and tuber inoculation as follows:

Blue green Algae: $\quad y=-0.350 x^{2}+1.450 x+17.300 \quad\left(R^{2}=1.000\right)$ control $\quad: \quad y=-0.085 x^{2}+0.602 x+12.190 \quad\left(R^{2}=0.407\right)$

\section{Water Use Efficiency:}

Figure (11) demonstrates that the higher water use efficiency value of $3.58 \mathrm{~kg} / \mathrm{m}^{3}$ was achieved using the subsoil tillage at $0.40 \mathrm{~m}$ depth under Blue green Algae application and tuber inoculation. Data indicate that the subsoil tillage depth of $0.30,0.400 .50 \mathrm{~m}$ increased the water use efficiency by about $152.00,176.00$ and $162.50 \%$ respectively of the water use efficiency value that was obtained in case of no-subsoil tillage. While, Blue green Algae application at subsoil tillage depth of 0.30, 0.40 and $0.50 \mathrm{~m}$ increased the water use efficiency by about $130.00,135.00$ and $132.00 \%$, respectively of the water use efficiency value that was obtaine by the bereaved of biofertilizer application. Whereas, the tuber inoculation at subsoil tillage depth of $0.30,0.40$ and $0.50 \mathrm{~m}$ increased the water use efficiency by about $110.00,108.00$ and $112.00 \%$, respectively of the water use efficiency that was obtaine incase of the bereaved of tuber incolation.

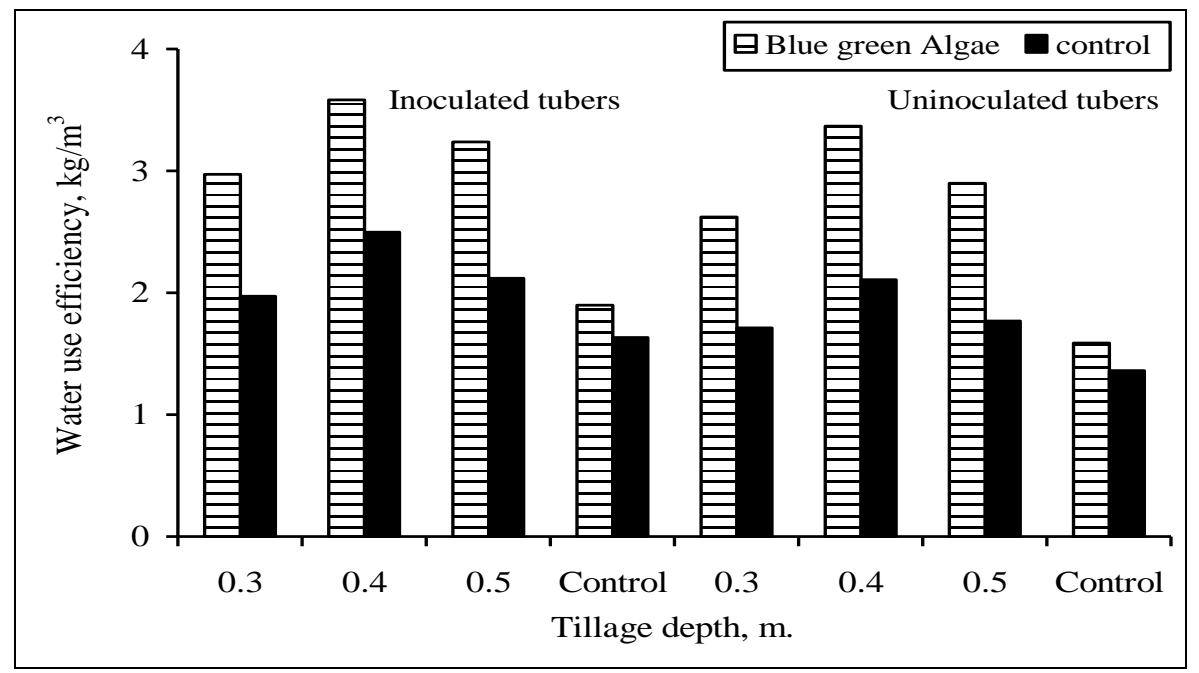

Fig. (11): Effect of subsoil tillage on potato water use efficiency. 


\section{CONCLUSION}

The obtained results of this study could be concluded as follows:

1. The subsoil tillage under biofertilizer application achieved the proper soil characteristics.

2. The subsoil tillage under biofertilizer application saved the total applied irrigation water amount.

3. The subsoil tillage under biofertilizer application and tuber inoculation produced the higher potato tuber yield and the reached the higher water use efficiency.

Finally, it is recommended to use the subsoil tillage under the biofertilizer application due to the desirable soil characteristics, the higher potato tuber yield and the higher water use efficiency.

\section{REFERENCES}

Abdulla, A.M. (1999). Effect of organic and biofertilization on growth, yield and its quality and storability of potato. Ph.D. Thesis, Fac. of Agric., Cairo Univ., 96 PP.

Alva, A.K.; T. Hodges; R.A. Boydston and H.P. Collins (2002). Effects of irrigation and tillage practices on yield of potato under high production conditions in the Pacific Northwest. Commun. Soil Sci. Plant Anal. 33: 1451-1460.

ASAE standard: S296.4 (1992). Cubes, Pellet, and crumbles-definitions and methods for determining density, durability and moisture content: 384 .

Awad, N.M. (1998). The use of microorganisms in ecological farming systems. Ph.D. Thesis, Fac. Sci., Cairo Univ., Egypt, 110 PP.

Black, C.A.; D.D.Even; J.L. White; L.E. Ensimenger and F.E. Clark (1965). Methods of soil analysis. Part 1, American Soc. Of Agromomy. Inc.. Publisher, Wisc., U.S.A.:

Doorenbos, J. and W.O. Prutt (1977). Guidline of predicting crop water requirements. Irrigation and drainage paperno 24 . FAO. 
El-Karamany, M.F.; M.K.A. Ahmed; A.A. Bahr and M.O. Kabesh (2000). Utilization of biio-fertilizers in field crop production. Egypt. J. Apple. Sci. 15 (11): 137.

El-Serafy, Z.M. and A.M. El-Ghamry (2006). Methods of soil and water analysis (Practices), Soils Dept., Fac, Ag., Mansoura Univ., 253 PP.

FAO (1979). Irrigation and drainge. Paper No. 33. Rome. Italy.

Garcia, I. (1978). Soil-Water Engineering. Laboratory Manual. Dept. of Agricultural and Chemical Engineering, Colorado State University, Fort Collins, Colorado, USA.

Halderson, J.L.; I.R. McCann and J.C. Stark (1993). Zoned tillage for potato production. ASAE 36: 1377-1380.

Hesse, P.P. (1971). A text book of soil chemical analysis. John Murray, pup., London Great Britan.

Higa, T. (1991). Effective microorganisms: A biotechnology for mankind. P.B. 14. In J.P. Parr, S.B. Hornic and C.E. Whitman (ed.). Proceeding of the First International Conference on Kyusei Nature Farming. U.S. Department of Agricultures, Washington, D.C., USA.

Holmstrom, D.A. and M.R. Carter (2000). Effect of subsoil tillage in the previous crop year on soil loosening and potato yield performance. Can. J. Plant Sci. 80: 161-164.

Ibrahim, B.A. and D.E. Miller (1989). Effect of subsoiling on yield and quality of corn and potato at two irrigation frequencies. Soil Sci. Soc. Am. J. 53: 247-251.

Israelson, O.W. and V.E. Hansen (1962). Irrigation Principles and Practices. $3^{\text {rd }}$ Ed. John Willey and Sons. Inc., New York, 265 pp.

James, L. G. (1988). Principles of farm irrigation system design. John Willey\&sons. Inc.,WashingMg State Univ., 73, 152-153 and 350-351.

Laboski, C.A.M.; R.H. Dowdy; R.R. Allmaras and J.A. Lamb (1998). Soil strength and water content influences corn root distribution in a sandy soil. Plant Soil 203: 239-247. 
Lowery, B. and R.T. Schuler (1994). Duration and effects of compaction on soil and plant growth in Wisconsin. Soil Tillage Res. 29: 205-210.

Miller, D.E. and M.W. Martin (1990). Responses of three early potato cultivars to subsoiling and irrigation regime on a sandy soil. Am. Potato J. 67: 769-777.

Ministry of Agriculture and Land Reclamation (2005). Potato planting and production. (In Arabic) Central administration for agricultural extension. Pamphlet No. 940.

Parr, J.F. and Hornick, S.B. (1994). Assessment of the Third International Conference on Kyusei Nature Farming: Round Table Discussion by USDA Scientists, October 7, 1993. Published by the Nature Farming Research and Development Foundation, Lompoc, California, USA.

Potato developed and training center (2001). The national program of potato cultivation.Egypt-Holland Chapter on potato mechanization: 109-138.

Stahlman, M.A. and E.J. Allen (2001). Effect of variety, irrigation regime and planting date on depth, rate, duration and density of root growth in potato (Solanum tuberosum) crop. J. Agric. Sci. 137: 251-270.

Stark, J. and S. Love (2003). Field selection, crop rotations, and soil management. p. 71-80. In J. C. Stark and S.L. Love (ed.) Potato production systems. Univ. of Idaho Agric. Communications, Moscow.

van Loon, C.D. and J. Bouma (1978). A case study on the effect of soil compaction on potato growth in a loamy sand soil. 2. Potato plant responses. Neth. J. Agric. Sci. 26: 421-429.

Wolkowski, R.P. (1990). Relationship between wheel-traffic-induced soil compaction, nutrient availability and crop growth: A review. J. Production Agric. 3: 460-469.

Wolfe, D.W.; D.T. Topoleski; N.A. Gundersheim and B.A. Ingall (1995). Growth and yield sensitivity of four vegetable crops to soil compaction. J. Am. Soc. Hortic. Sci. 120: 956-963. 


\section{الملخص العربي}

\section{تأثير الحرث تحث التربة على إستجابة البطاطس للتخصيب الحيوي

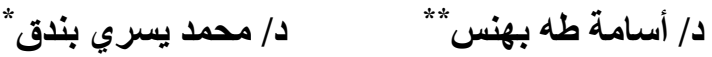

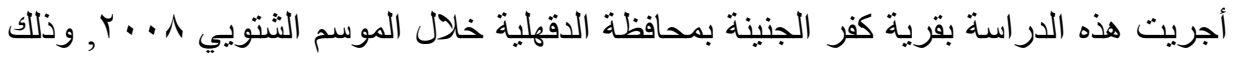
للوقوف على تأثثر الحرث تحت التربة على إسجابة البطاطس للتخصيب الحيوي, وقد تم تصميم التجربة إحصائياً في قطع تحت منشقة في ثلاثة مكرر ات, وقد تضمنت القيجة القطع الرئيسة معاملة الحرث تحت التربة عند أعماق • r, •, • ع , •, • 0, • م, بينما إثتملت القطع الثقية على معاملة التخصيب الحيوي للتربة باستخدام المخصب بلوجرين بالمقارنة مع عدم التخصيب الحيوي

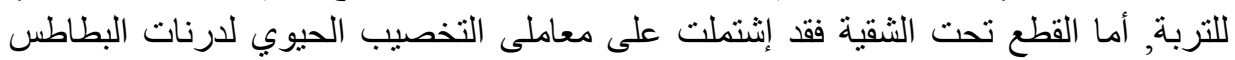

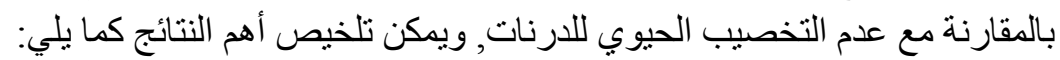

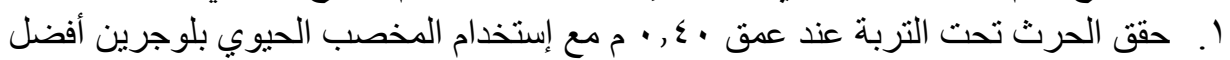

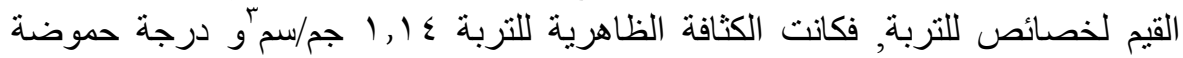

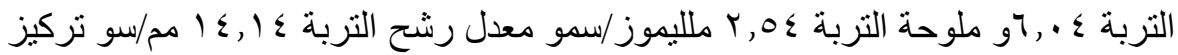

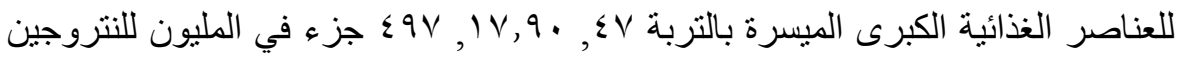
و الفوسفور و البوتاسيوم على الترتيب.

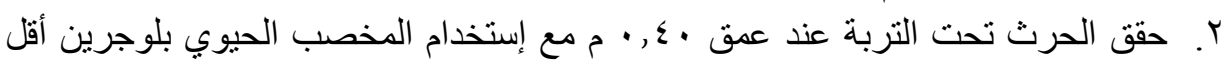

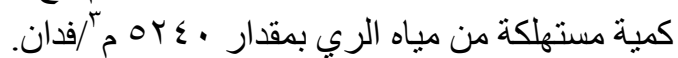

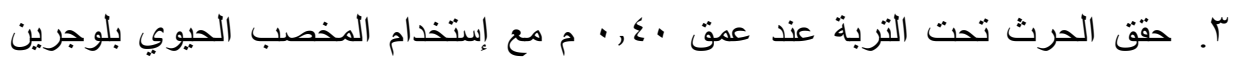

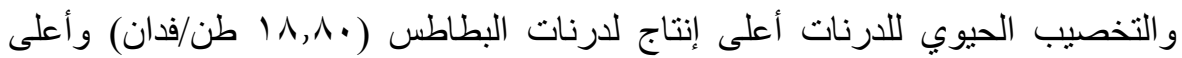

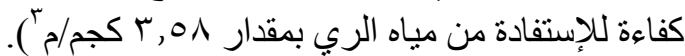

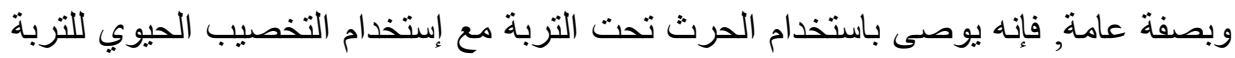
ولدرنات البطاطس, وذلك لتحقيق أعلى إنتاج لدرنات البطاطس مع توفير أكبر قدر ممكن من فن مياه الري.

$$
\begin{aligned}
& \text { ** باحث أول بمعهد بحوث الهندسة الزر اعية ـ مركز البحوث الزر اعية ـ الجيزة. } \\
& \text { * باحث بمعهد بحوث الهندسة الزر اعية ـ مركز البحوث الزر اعية ــ الجيزة. }
\end{aligned}
$$

